\title{
Glucose-stimulated Phosphorylation of Yeast Isocitrate Lyase in vivo
}

\author{
By Y. S. LÓPEZ-BOADO, P. HERRERO, T. FERNÁNDEZ, \\ R. FER NÁNDEZ AND F. MORENO* \\ Departamento de Biología Funcional, Area de Bioquimica y Biología Molecular, Facultad de \\ Medicina, Universidad de Oviedo, 33071-Oviedo, Spain
}

(Received 29 February 1988; revised 19 May 1988)

\begin{abstract}
Incorporation of ${ }^{32} \mathrm{P}$ into Saccharomyces cerevisiae isocitrate lyase was observed after addition of glucose to a culture incubated with [ $\left.{ }^{32} \mathrm{P}\right]$ orthophosphoric acid. A band of ${ }^{32} \mathrm{P}$-labelled protein was coincident with the enzyme band when immunoprecipitates were subjected to SDS-PAGE and autoradiography. No label was found in the band corresponding to the isocitrate lyase when immunoprecipitation was done with a control pre-immune serum or in the presence of excess pure unlabelled enzyme. The incorporation of phosphate was associated with a decrease in enzyme activity. Phosphorylated isocitrate lyase was not proteolytically degraded when cells were cultured in mineral medium. The loss of protein antigenicity only took place when the yeast was grown in a complex medium containing glucose.
\end{abstract}

\section{INTRODUCTION}

Addition of glucose to Saccharomyces cerevisiae cells adapted to grow on ethanol causes a timedependent disappearance of several enzymes. These enzymes include the glyoxalate cycle enzyme isocitrate lyase (EC 4.1.3.1) (Herrero et al., 1985) and three cytoplasmic enzymes: malate dehydrogenase (Witt et al., 1966), phosphoenolpyruvate carboxykinase (Haarasilta \& Oura, 1975) and fructose-1,6-bisphosphatase (Gancedo \& Gancedo, 1971).

Fructose-1,6-bisphosphatase has been extensively studied as a model for the understanding of the mechanism of catabolite inactivation in yeasts. The glucose-induced inactivation of fructose-1,6-bisphosphatase involves a two-step process (Lenz \& Holzer, 1980), the first related to the reversible phosphorylation of the enzyme (Mazón et al., 1982; Purwin et al., 1982), and the second step involving the loss of enzymic activity parallel to the loss of protein antigenicity (Funayama et al., 1980; Tortora et al., 1981), suggesting a proteolytic mechanism.

Catabolite inactivation studies on malate dehydrogenase and phosphoenolpyruvate carboxykinase showed that the loss of activity is irreversible at all stages of inactivation (Gancedo \& Schwerzmann, 1976). No data are available on phosphorylation of these enzymes during incubation with glucose (Tortora et al., 1983).

In a previous paper we showed that the kinetics of the glucose-induced catabolite inactivation of isocitrate lyase involves two phases. Within $30 \mathrm{~min}$ of glucose addition, the enzyme is reversibly inactivated. During the following $2 \mathrm{~h}$, isocitrate lyase activity decreases slowly and irreversibly until only $40 \%$ of the initial activity remains (López-Boado et al., 1987). In the present paper, it is demonstrated that yeast isocitrate lyase is phosphorylated after addition of glucose to a cell culture.

\section{METHODS}

Chemicals. Material for electrophoresis was from Bio-Rad. [32P]Orthophosphoric acid (carrier free) was purchased from New England Nuclear. All other chemicals used were of analytical grade.

Abbreviations: PMSF, phenylmethylsulphonyl fluoride; TBS, Tris-buffered saline. 
Organism and culture conditions. Saccharomyces cerevisiae G-517, number 1317 in the Spanish Collection of Yeast Cultures (CECT, Departamento de Microbiología, Facultad de Biología, Universidad de Valencia) was used in this work. The organism was grown on a medium containing $1 \%(\mathrm{w} / \mathrm{v})$ yeast extract, $2 \%(\mathrm{w} / \mathrm{v})$ Bacto-peptone and $3 \%(v / v)$ ethanol (YPE) with aeration at $30^{\circ} \mathrm{C}$. Growth was followed by determination of the optical density at $600 \mathrm{~nm}$. Cells were harvested from the cultures at an optical density of $3 \cdot 0$, in order to obtain suitable derepression of enzymes.

Experimental conditions for labelling with ${ }^{32} P$. A culture of $S$. cerevisiae grown in YPE medium until reaching an optical density of 3.0 was washed with sterile water and used to inoculate, at the same cell density, a mineral medium lacking inorganic phosphate (Kitazume et al., 1962) and with $3 \%(\mathrm{v} / \mathrm{v})$ ethanol as a carbon source. After $60 \mathrm{~min}$ incubation with shaking at $30^{\circ} \mathrm{C},\left[{ }^{32} \mathrm{P}\right]$ orthophosphoric acid $\left(10 \mu \mathrm{Ci} \mathrm{ml}^{-1} ; 370 \mathrm{kBq} \mathrm{ml}^{-1}\right)$ was added and the suspension was further incubated for $60 \mathrm{~min}$. The culture was divided and placed in two flasks, one receiving glucose to a final concentration of $2 \%(\mathrm{w} / \mathrm{v})$ and the other an equivalent volume of sterile water. During the catabolite inactivation experiment $10 \mathrm{ml}$ samples were withdrawn from the cultures at various times and the cells were harvested by centrifugation at $4000 \mathrm{~g}$ for $3 \mathrm{~min}$ and washed once with distilled water.

Cell-free extracts were prepared by shaking a suspension of cells in $1 \mathrm{ml} 10 \mathrm{~mm}$-potassium phosphate buffer, $\mathrm{pH}$ 7.0, containing $1 \mathrm{mM}$-EDTA, $4 \mathrm{mM}$-phenylmethylsulphonyl fluoride (PMSF) and $4 \mathrm{~mm}$-sodium fluoride, with glass beads in a vortex mixer for five $1 \mathrm{~min}$ intervals alternating with $1 \mathrm{~min}$ intervals of cooling in ice. The liquid was carefully removed and centrifuged at $12000 \mathrm{~g}$ for $10 \mathrm{~min}$. The supernatants were used for enzyme assays, immunoprecipitation experiments and SDS-PAGE. PMSF and sodium fluoride were included in the extraction buffer as proteinase and phosphatase inhibitors respectively.

Purification of isocitrate lyase. Isocitrate lyase was purified to homogeneity as described by López-Boado et al. (1988).

Immunization of rabbits. Antisera against homogeneously prepared isocitrate lyase were raised by injecting rabbits with $0 \cdot 1 \mathrm{mg}$ protein at 1 week intervals as described by Fernández et al. (1987).

Immunopurification of isocitrate lyase. Isocitrate lyase was specifically immunoprecipitated from crude extracts with antisera and protein A-Sepharose as described by Anderson \& Blobel (1983). Anti-isocitrate lyase serum $(15 \mu \mathrm{l})$ was added to $200 \mu \mathrm{l}$ of cell-free extract containing $0.6 \mathrm{mg}$ protein. After incubation at $4{ }^{\circ} \mathrm{C}$ for $60 \mathrm{~min}$, $200 \mu 1$ of a suspension of protein A-Sepharose CL-4B ( $5 \mathrm{mg}$ per tube) were added, and the sample was incubated with shaking at $4{ }^{\circ} \mathrm{C}$ for $30 \mathrm{~min}$. The Sepharose beads were pelleted by a $2 \mathrm{~min}$ centrifugation and the supernatant was discarded. The beads were washed four times in $1 \mathrm{ml}$, per wash, of $1 \%(\mathrm{v} / \mathrm{v})$ Triton $\mathrm{X}-100,0 \cdot 1 \%(\mathrm{w} / \mathrm{v})$ SDS, $0.5 \%(\mathrm{w} / \mathrm{v})$ sodium deoxycholate, $100 \mathrm{~mm}-\mathrm{NaCl}, 0 \cdot 1 \%(\mathrm{w} / \mathrm{v})$ sodium azide, $10 \mathrm{~mm}$-potassium phosphate buffer, pH 7.5, with vortexing at each wash. SDS-gel electrophoresis sample buffer $(30 \mu 1)$ (Britton et al., 1982) was finally added to the beads, and the sample was heated for $5 \mathrm{~min}$ in a boiling water-bath. The beads were centrifuged out, and the supernatant was applied to a SDS-polyacrylamide slab gel.

Electrophoresis. SDS-PAGE was done according to the method of Britton et al. (1982). Gels were dried and exposed to X-ray films for autoradiography.

Immunoblotting. Proteins were electrophoretically transferred from the SDS-electrophoresis slab gel to a nitrocellulose sheet by the method described previously (Fernández et al., 1987). The nitrocellulose sheet was

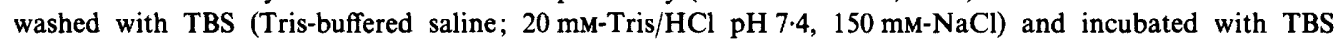
containing $3 \%(\mathrm{w} / \mathrm{v})$ BSA for $2 \mathrm{~h}$ at room temperature. The TBS-BSA was removed and the sheet was washed once in $5 \mathrm{ml}$ TBS for $2 \mathrm{~min}$. The nitrocellulose sheet was further incubated with antiserum containing TBS plus $3 \%$ $(\mathrm{w} / \mathrm{v}$ ) BSA for $2 \mathrm{~h}$, and washed five times, $5 \mathrm{~min}$ each, with wash buffer (TBS containing $0.6 \%, \mathrm{w} / \mathrm{v}, \mathrm{NaCl}$ and $0 \cdot 3 \%, \mathrm{v} / \mathrm{v}, \mathrm{NP}-40$ ). Then the nitrocellulose sheet was incubated at $25^{\circ} \mathrm{C}$ for $1 \mathrm{~h}$ with a second antirabbit antibody peroxidase conjugate. After incubation the nitrocellulose sheet was washed three times with wash buffer and twice with TBS, then incubated at $25^{\circ} \mathrm{C}$ with $3 \mathrm{mg}$ 4-chloro-1-naphthol dissolved in $1 \mathrm{ml}$ methanol, $5 \mathrm{ml}$ TBS and $10 \mu \mathrm{l}$ $30 \%$ (v/v) $\mathrm{H}_{2} \mathrm{O}_{2}$. The reaction was stopped by washing the nitrocellulose sheet several times with distilled water and the strip was dried on filter paper.

Scanning procedure. The ${ }^{32} \mathrm{P}$-labelled isocitrate lyase detected by autoradiography or the isocitrate lyase protein present in the nitrocellulose sheet were determined from the area of the peak obtained by scanning for absorbance at $560 \mathrm{~nm}$ with a Joyce Loebl scanner.

Enzyme and protein assays. Isocitrate lyase was assayed spectrophotometrically as described by Dixon \& Kornberg (1959). Protein was determined by the method of Lowry using BSA as standard.

\section{RESULTS}

\section{Incorporation of phosphate into isocitrate lyase}

The phosphorus-containing pools of yeast cells were labelled with $\left.{ }^{32} \mathrm{P}\right]$ orthophosphate in ethanol mineral medium, lacking inorganic phosphate, in which $S$. cerevisiae was grown. Under these conditions isocitrate lyase synthesis is derepressed and addition of glucose to the culture induces the catabolite inactivation of the enzyme (López-Boado et al., 1987). Samples were 


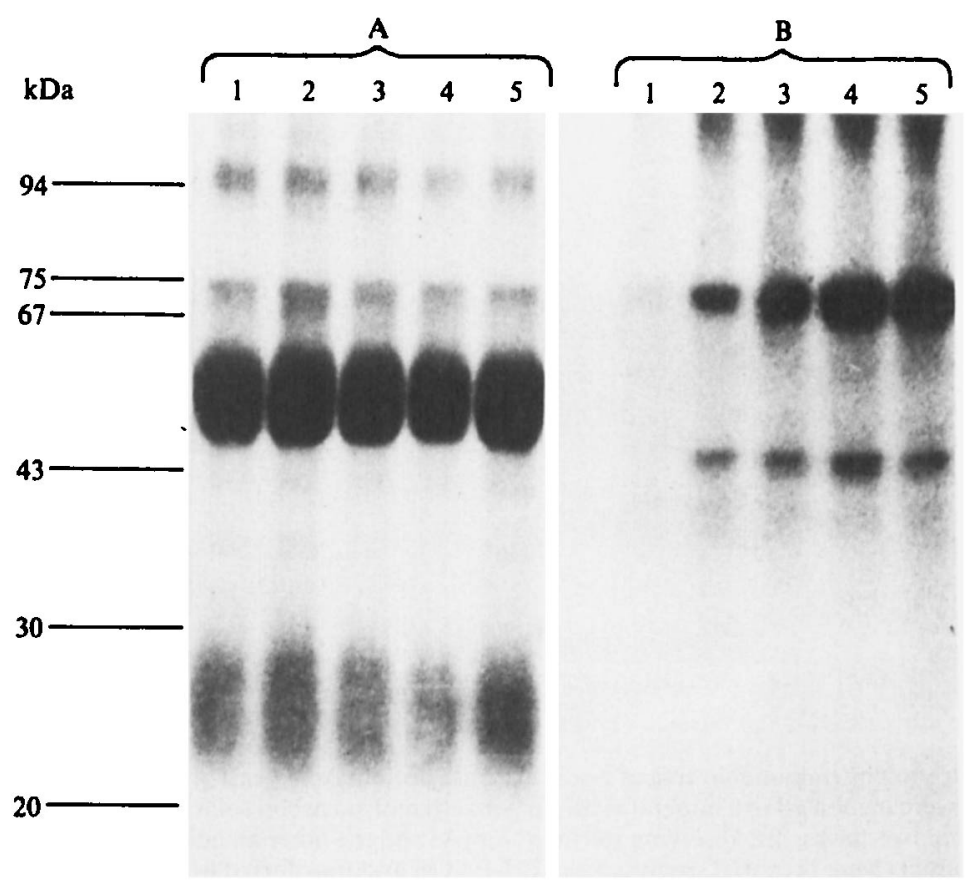

Fig. 1. Analysis by SDS-PAGE of proteins immunoprecipitated with anti-isocitrate lyase antiserum (A) and corresponding autoradiogram showing ${ }^{32} \mathrm{P}$-incorporation into isocitrate lyase (B). Yeast cells were incubated in low-phosphate mineral medium in the presence of $\left[{ }^{32} \mathrm{P}\right]$ orthophosphoric acid. Samples $(10 \mathrm{ml})$ were taken $0,30,60,90$ and $120 \mathrm{~min}$ after addition of glucose (lanes 1 to 5 respectively) and extracted as described in Methods. Isocitrate lyase was precipitated with specific antibody and the immunoprecipitate was subjected to SDS-PAGE (A), followed by autoradiography on X-ray film (B).

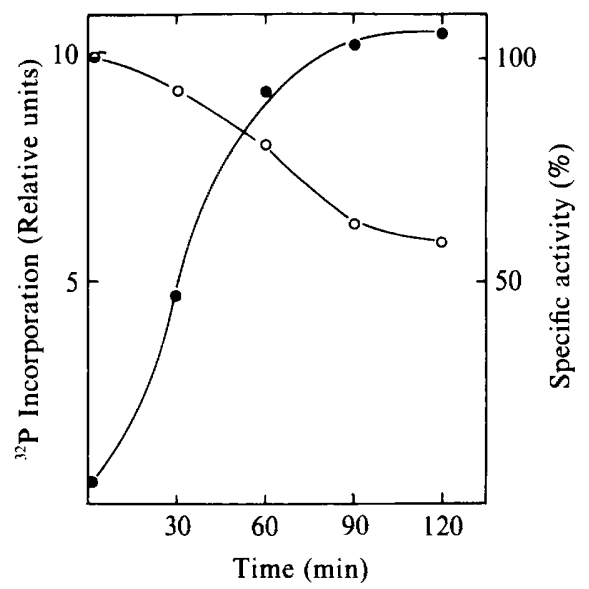

Fig. 2. Inactivation and phosphorylation of yeast isocitrate lyase in vivo. Yeast cells were grown and treated with glucose in the presence of $\left[{ }^{32} \mathrm{P}\right]$ orthophosphoric acid as described in Methods. Cell-free extracts were prepared and then immunoprecipitated and processed as in Fig. 1. O, Specific activity of isocitrate lyase $\left(100 \%\right.$ specific activity corresponds to $\left.350 \mathrm{mU} \mathrm{mg}^{-1}\right) ;{ }^{32} \mathrm{P}$ incorporation into isocitrate lyase, measured from the area of the peak obtained by scanning at $560 \mathrm{~nm}$ (expressed as relative units).

collected by centrifugation from the derepressed cells and the glucose-inactivated cells in order to prepare cell-free extracts. In the cell-free extracts specific catalytic activity of isocitrate lyase was assayed. In addition, isocitrate lyase was immunoprecipitated and analysed by SDS-PAGE (Fig. 1 A). An autoradiogram of the immunoprecipitated proteins separated by SDS-PAGE is shown in Fig. 1(B). It can be seen that, under the conditions of cultivation used, there is a clear 


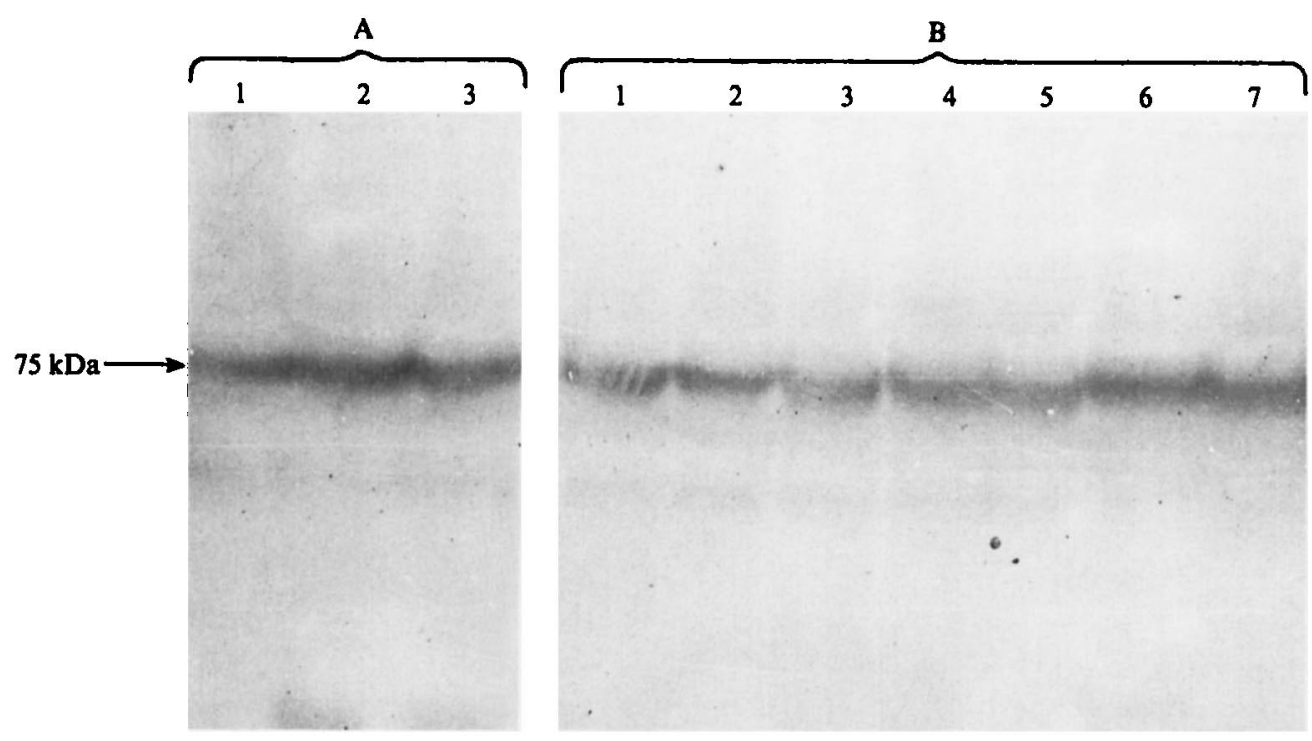

Fig. 3. Detection by immunoblotting of isocitrate lyase protein from yeast grown in a mineral medium. Yeast cells were incubated in a mineral medium with ethanol as carbon source. The culture was divided and placed in two flasks, one receiving sterile water (A) and the other an equivalent volume of glucose (B). Cell extracts were prepared, analysed by SDS-PAGE and transferred to a nitrocellulose sheet. The filter was then stained using a peroxidase reaction to show the position of rabbit antibody against isocitrate lyase adsorbed during the immunoblotting procedure. A, Samples ( $75 \mu \mathrm{g}$ protein) taken 60 , 120 and $240 \mathrm{~min}$ after addition of water (lanes 1 to 3 ). B, Samples $(75 \mu \mathrm{g}$ protein) taken $0,30,60,90,120$, 180 and $240 \mathrm{~min}$ after addition of glucose (lanes 1 to 7 ).

band of ${ }^{32} \mathrm{P}$-labelled protein at $75 \mathrm{kDa}$, which corresponds with the molecular mass that has been described for the isocitrate lyase subunit (López-Boado et al., 1988). Fig. 2 shows that the incorporation of phosphate parallels the loss of specific activity of the enzyme. Phosphate incorporation is maximal about $90 \mathrm{~min}$ after the addition of glucose. In control cultures incubated without glucose, neither ${ }^{32} \mathrm{P}$ incorporation into isocitrate lyase nor inactivation of the enzyme was observed. Incorporation into isocitrate lyase was checked by carrying out the immunoprecipitation with control sera obtained from the same rabbits prior to the first injection of antigen or with an added excess of pure unlabelled enzyme. Under these conditions no label was found in the band corresponding to isocitrate lyase.

\section{Behaviour of the isocitrate lyase protein during enzyme inactivation}

$S$. cerevisiae was grown in two different media: a mineral medium lacking inorganic phosphate and containing ethanol as carbon source, and YPE medium. In both cases the cultures were divided and placed in two flasks, one receiving glucose and the other an equivalent volume of sterile water. Samples were collected by centrifugation, and cell-free extracts were prepared as described in Methods.

The extracts were analysed by SDS-PAGE and the proteins $(75 \mu \mathrm{g})$ were transferred from the gel to a nitrocellulose sheet. The isocitrate lyase protein present on the nitrocellulose sheet was identified by using anti-isocitrate lyase antibodies and was determined from the area of the peak obtained by scanning for absorbance at $560 \mathrm{~nm}$ with a Joyce Loebl scanner.

There were no changes in the total amount of isocitrate lyase protein in yeast cells harvested at different culture times from mineral medium (Fig. 3), whereas there was an evident loss of isocitrate lyase protein in yeast cells harvested from YPE medium (Fig. 4). As can be seen in Fig. 


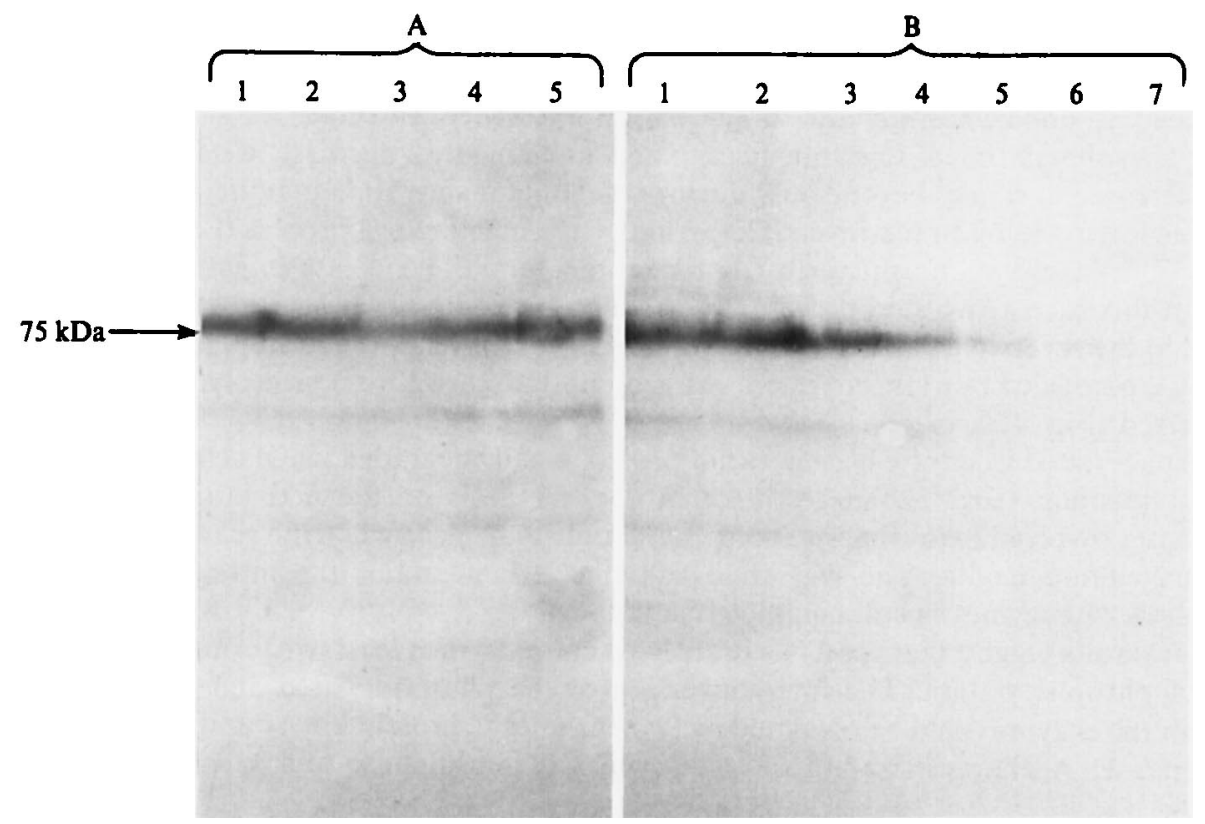

Fig. 4. Detection by immunoblotting of isocitrate lyase protein from yeast grown in a complex medium. Cells were grown in a complex medium (YPE) with ethanol as carbon source. The culture was divided and placed in two flasks, one receiving sterile water (A), and the other an equivalent volume of glucose (B). Cell extracts were prepared and analysed by SDS-PAGE. The proteins were electrophoretically transferred to a nitrocellulose sheet for detection of isocitrate lyase by immunoblotting as in Fig. 3. A, Samples ( $75 \mu$ g protein) taken $30,60,120,180$ and $240 \mathrm{~min}$ after addition of water (lanes 1 to 5 ). B, Samples ( $75 \mu \mathrm{g}$ protein) taken $0,30,60,90,120,180$ and 240 min after addition of glucose (lanes 1 to 7 ).

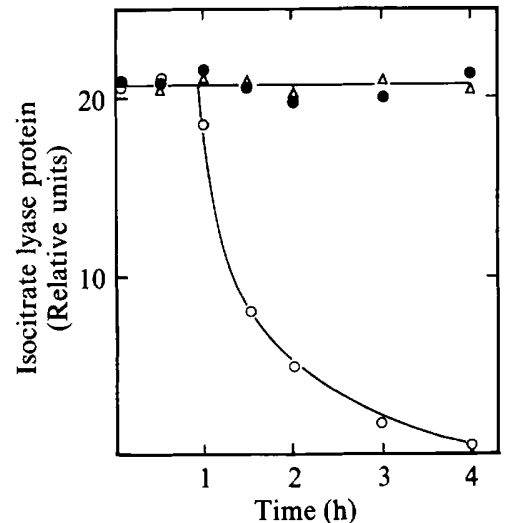

Fig. 5. Fate of cross-reacting material against isocitrate lyase antibodies during inactivation by glucose. The amount of isocitrate lyase protein was determined from the immunoblots by measuring the area of the peak obtained by scanning at $560 \mathrm{~nm}$ (expressed as relative units). $\triangle$, Isocitrate lyase crossreacting material from cells growing in a mineral medium after addition of glucose; $\boldsymbol{O}$, isocitrate lyase cross-reacting material from cells growing in YPE medium; $O$, isocitrate lyase cross-reacting material from cells growing in YPD medium.

5 , there was a loss of antigenic material $1 \mathrm{~h}$ after addition of glucose to the YPE culture. This suggests that the enzyme was considerably altered, rendering the antigen unrecognizable to the anti-serum. No proteolytic peptide intermediates of isocitrate lyase were detected during catabolite inactivation. 


\section{DISCUSSION}

The results presented in this work clearly demonstrate that phosphorylation of isocitrate lyase is induced by addition of glucose to glucose-derepressed yeast cells.

The phosphorylation of isocitrate lyase is accompanied by a decrease in its enzymic activity. This decrease never goes beyond $40 \%$ during catabolite inactivation in mineral medium (Figs 1 and 2), corresponding to the reversible period of the inactivation process (López-Boado et al., 1987). With inactivation using cells from YPE medium, the decrease in activity progresses to $70 \%$. In this case a two-step process is involved (López-Boado et al., 1987). The first step is related to the reversible phosphorylation of the enzyme; in the second step, the loss of enzymic activity is paralleled by a loss of protein antigenicity and, therefore, a proteolytic mechanism can be inferred (Fig. 4).

Phosphorylated isocitrate lyase was not proteolytically degraded when cells were cultured in mineral medium (Fig. 3), suggesting that the synthesis or the activation of pre-existing proteinases involved in the inactivation process only took place when the yeasts were growing in complex culture media. The way in which the carbon and/or the nitrogen sources affect proteolysis of enzymes is still completely unknown.

These results suggest that yeast isocitrate lyase can exist in at least two forms, differing in their state of phosphorylation. The interconversion of the phosphorylated and dephosphorylated forms of the enzyme could be regulated by two enzymes: a protein kinase and a phosphoprotein phosphatase. A characterization of the postulated phosphatase and kinase is currently in progress.

The authors thank Professor S. Gascon for his interest in this work and the many interesting suggestions and Dr F. Leal for his help with the immunoprecipitation experiments. This work was supported by grants from the Comisión Asesora de Investigación Científica y Técnica (340/84) and from the Fondo de Investigaciones Sanitarias de la Seguridad Social.

\section{REFERENCES}

ANDERSON, D. J. \& Blobel, G. (1983). Immunoprecipitation of proteins from cell-free translations. Methods in Enzymology 96, 111-120.

Britton, P., Murfitt, D., Parra, F., Jones-MorTIMER, M. C. \& KornberG, H. L. (1982). Phosphotransferase-mediated regulation of carbohydrate utilisation in Escherichia coli $\mathrm{K} 12$ : identification of the products of genes on the specialised transducing phages $\lambda$ iex (crr) and $\lambda$ gsr (tgs). EMBO Journal 1, 908-911.

Dixon, G. H. \& KornberG, H. L. (1959). Assay methods for key enzymes of the glyoxalate cycle. Biochemical Journal 72, 3.

FERnÁNDEZ, M. T., HerRero, P., López-BoAdo, Y., FERNÁNDEZ, R. \& MoRenO, F. (1987). Proteolysis of hexokinase PII is not the triggering signal of carbon catabolite derepression in Saccharomyces cerevisiae. Journal of General Microbiology 133, 2509-2516.

Funayama, S., Gancdo, J. M. \& Gancedo, C. (1980). Turnover of yeast fructose-1,6-bisphosphatase in different metabolic conditions. European Journal of Biochemistry 109, 61-66.

GANCEDO, J. M. \& GANCEDO, C. (1971). Fructose-1,6bisphosphatase, phosphofructo-kinase and glucose6-phosphate dehydrogenase from fermenting and non-fermenting yeast. Archives of Microbiology 76, 132-138.

GANCEDO, C. \& SCHWERTzMANN, K. (1976). Inactivation by glucose of phosphoenol-pyruvate carboxykinase from Saccharomyces cerevisiae. Archives of Microbiology 109, 221-225.
HaArasilta, S. \& OURA, E. (1975). On the activity and regulation of anaplerotic and gluconeogenetic enzymes during the growth process of baker's yeast. The biphasic growth. European Journal of Biochemistry 52, 1-7.

Herrero, P., Fernández, R. \& Moreno, F. (1985). Differential sensitivities to glucose and galactose repression of gluconeogenic and respiratory enzymes from Saccharomyces cerevisiae. Archives of Microbiology 143, 216-219.

KitaZUME, Y., YCAS, M. \& Vincent, W. S. (1962). Metabolic properties of a ribonucleic acid fraction in yeast. Proceedings of the National Academy of Sciences of the United States of America 48, 265269.

LENZ, A. G. \& Holzer, H. (1980). Rapid reversible inactivation of fructose-1,6-bisphosphatase in Saccharomyces cerevisiae by glucose. FEBS Letters 109 , 271-274.

López-Boado, Y. S., Herrero, P., Gascon, S. \& MORENO, F. (1987). Catabolite inactivation of isocitrate lyase from Saccharomyces cerevisiae. Archives of Microbiology 147, 231-234.

López-BoAdo, Y.S., HerRero, P., FERnÁNDEZ, M. T., FERnÁndez, R. \& MoReno, F. (1988). Purification of isocitrate lyase from Saccharomyces cerevisiae. Yeast 4, 41-46.

Mazon, M. J., Gancedo, J. M. \& Gancedo, C. (1982). Inactivation of yeast fructose-1,6-bisphosphatase. In vitro phosphorylation of the enzyme. Journal of Biological Chemistry 257, 1128-1130. 
Purwin, C., Leidig, F. \& Holzer, H. (1982). Cyclic AMP-dependent phosphorylation of fructose-1,6bisphosphatase in yeast. Biochemical and Biophysical Research Communications 107, 1482-1489.

Tortora, P., Birtel, M., Lenz, A. G. \& Holzer, H. (1981). Glucose-dependent inactivation of fructose1,6-bisphosphatase in yeast. Biochemical and Biophysical Research Communications 100, 689-695.
Tortora, P., Burlini, N., Leoni, F. \& Guerritore, A. (1983). Dependence of cyclic AMP of glucoseinduced inactivation of yeast gluconeogenetic enzymes. FEBS Letters 155, 39-42.

WitT, I., KronaU, R. \& Holzer, H. (1966). Repression von Alkoholdehydrogenase, Malatdehydrogenase, Isocitratlyase und Malatsynthase in Hefe durch Glucose. Biochimica et biophysica acta 118, 522-537. 